\title{
Do Firm Characteristics and Industry Matter in Determining Corporate Cash Holdings? Evidence from Hospitality Firms
}

\author{
Jing-Hui KWAN*, Wee-Yeap LAU ${ }^{* *}$
}

Received: June 30, 2019 Revised: December 11, 2019 Accepted: December 18, 2019

\begin{abstract}
The study investigates a recent surge of cash literature by using a sample of hospitality firms to gain a new understanding of corporate cash holdings. Past literature states that there is a substantial variation of liquidity across industry groups. Existing literature predominantly refers to US-listed firms and focus on either hotels or restaurants and not the hospitality industry as a whole. Therefore, we provide a comparative study of cash holdings behaviour between hospitality and non-hospitality firms from an emerging market context. Using a sample of public listed hospitality firms from 2002 to 2013, dynamic panel regression techniques are used to study the relationships between firm characteristics and cash levels. Also, the non-parametric Wilcoxon-Mann-Whitney test was carried out to examine the time and sectoral differences in cash holdings. In addition, the panel regression techniques are used to investigate the relationships between firm characteristics and level of corporate cash holdings. The results reveal that firm characteristics do matter in hospitality firms. We find that firm size, capital expenditures, and liquid assets substitutes are negatively related to cash level. The results support trade-off theory and the pecking order theory. This study incrementally explains the cash holdings behaviour of hospitality firms in emerging market.
\end{abstract}

Keywords: Corporate Liquidity, Pecking Order Theory, Trade-off Theory

JEL Classification Code: G32, G34, D92

\section{Introduction}

Corporate cash holdings constitute an essential area in the literature. The empirical studies on the determinants of corporate cash holding gained a growing interest in recent years. This growth is driven by the observed increasing trend of firms hoarding unusually high level of cash. There is a substantial upward trend observed among firms around the world in recent years. Non-financial firms maintain a sizable portion of their assets as cash. It is evident that companies choose to hold more cash across industries in

${ }^{*}$ First Author and Corresponding Author. Lecturer, Faculty of Management, Multimedia University, Malaysia [Postal Address: Persiaran Multimedia, 63100 Cyberjaya, Selangor, Malaysia]

Tel: + 60383125682 Email: jhkwan@mmu.edu.my

${ }^{* *}$ Associate Professor, Faculty of Economics and Administration, University of Malaya, 50603 Kuala Lumpur, Malaysia.

Email: wylau@um.edu.my

$\odot$ Copyright: Korean Distribution Science Association (KODISA)

This is an Open Access article distributed under the terms of the Creative Commons Attribution NonCommercial License (https://creativecommons.org/licenses/by-nc/4.0/) which permits unrestricted noncommercial use, distribution, and reproduction in any medium, provided the original work is properly cited. recent years. Opler et al. (1999) were among the pioneers to investigate the determinants of cash holdings. Some of the past studies include: industrial firms (Bates \& Kahle, 2009; Kim, Mauer, \& Sherman, 1998; Opler et al., 2001); insurance (Hsu, Huang, \& Lai, 2015); high tech firms (Booth \& Zhou, 2013; Chen, 2008); Real Estate Investment Trust (REITs) (Hardin, Highfield, Hill, \& Kelly, 2009); and, inter-industries (Opler et al., 1999; Ozkan \& Ozkan, 2004).

However, the increasing level in corporate cash holdings is not pervasive across all industries. Unlike other sectors, the hospitality industry has not shown a similar trend in cash holdings over the same period despite the observed increase in cash holding levels in other industries in recent years. Nonetheless, the hospitality industry is one of the industries which have lower reserves of cash holdings including in emerging market such as Malaysia. Even though the unusual trend of holding a low level of cash reserves in the hospitality industry is observed, there is only a handful of researches done. The tendency to avoid large cash balances in the hospitality industry thus raises important research questions. 
Several attributes of hospitality firms may explain the puzzle of unusual cash holding phenomenon. Past studies show that hospitality firms differ from other firms regarding investment and financing policies (Oak \& Iyengar, 2009). The unique corporate governance structures and agency problems in hospitality firms may contribute to such behaviour. Hospitality firms such as restaurants had been characterised as a business that experiences cyclical patterns and strong seasonality (Choi, Roh, \& Yoon, 2007; Upneja \& Dalbor, 2000). They operate in a highly competitive environment. Hospitality firms are also constantly challenged by high financial and operational risks (Kim, Kim, \& Woods, 2011). Furthemore, Pizam and Shani (2009) compare hospitality firms with manufacturing companies regarding labour and capital intensity. They argue that hospitality firms are labour-intensive compared to other firms such as manufacturing. Also, hospitality firms tend to invest significantly in real estate and fixed assets which are highly illiquid as compared to firms in other industries (Bharwani \& Mathews, 2012). Thus, hospitality firms are susceptible to volatile macroeconomic factors and financial environment.

Firms may face challenges in dealing with the changes efficiently. Moreover, hospitality firms are also subject to interest rate risk as companies have high debts (Jang, Tang, $\&$ Chen, 2008). Besides, hospitality firms are exposed to seasonality and high volatility in operating cash flows (Hsu \& Jang, 2008; Pegg, Patterson, \& Gariddo, 2012; Scott \& McBoyle, 2007). Financially constrained firms may leave with no options, but to use the external financing to fulfil operational and investment needs due to the variability of internal cash flows. In some cases, companies may have to forgo opportunities as a result of high costs of capital. Therefore, cash management is essential for hospitality firms during good times and even more so during uncertain economic conditions.

This study intends to narrow the gap in the present studies on corporate cash holdings by tackling the question based on the hospitality industry perspective suggested Jang, Park, and Lee (2011) and Park and Jang (2014). According to these authors, although extensive research had been done in the hospitality industry, however, focus on financial management such as corporate cash holdings are lacking. In response to the calling, we included hospitality firms which are publicly listed on Bursa Malaysia and compared cash holdings behaviours with non-hospitality firms from the year 2002 to 2013. This study aims to add to the literature by investigating the financial determinants of corporate cash holdings in hospitality firms in Malaysia. A comparative study of hospitality and non-hospitality firms are conducted. This study allows further examination of corporate cash holdings across industries with various institutional frameworks.

The remainder of this paper is organised as follows. Section 2 presents a brief literature review and formulation of research hypotheses. The section is followed by Section 3 where the detailed methodology adopted in this study is shown. Empirical results and discussion are discussed in Section 4. Finally, Section 5 concludes the study and indicates its theoretical and practical implications.

\section{Literature Review and Hypotheses Development}

There are several variables which are related to the determinants of cash holdings. The expected link between these variables and cash holdings are discussed as following and then summarised in Table 1

Table 1: Variables measurement and theoretical predictions

\begin{tabular}{|c|c|c|c|c|}
\hline Variable & Variable name & Measurement & Pecking Order Theory & Trade-off Theory \\
\hline Financial Variables & & & + & - \\
\hline Size & SIZE & Natural logarithm of total assets & + & - \\
\hline Cash flow & CF & $\begin{array}{c}\text { (Earnings before tax }+ \text { depreciation \& amo } \\
\text { rtization) / Total assets }\end{array}$ & + & + \\
\hline Growth opportunities & GRO & Market to book ratio & $+/-$ & - \\
\hline Leverage & LEV & Total liabilities/ Total assets & - \\
\hline Dividend & DIV & $\begin{array}{c}\text { Dummy variable: 1- if the dividend is pai } \\
\text { d; } 0=\text { if the dividend is not paid }\end{array}$ & + \\
\hline Capital expenditures & CAPEX & Total capital expenditures & - \\
\hline $\begin{array}{c}\text { Liquidity asset substit } \\
\text { utes }\end{array}$ & LIQ & $\begin{array}{c}\text { (Current assets- current liabilities- cash \& } \\
\text { equivalents)/ Total assets. }\end{array}$ & + \\
\hline Debt structure & STDEBT & Short-term debt/ Total Liabilities & & + \\
\hline
\end{tabular}

\subsection{Growth Opportunities}

For firms having high growth opportunities, it is imperative that they have enough funds to exploit these opportunities. They do not want to forgo these promising investments, so they ought to hold liquid assets to be sure to have the necessary funds available when investment opportunities arise. Thus, firms with more or better growth 
opportunities tend to keep higher cash balances to prevent losing valuable investment opportunities due to a shortage of funds. Also, these cash balances are more highly valued by investors, in anticipation of future growth (Opler et al., 1999). Growth opportunities are also linked to the costs of agency costs resulted from the conflicts of interest between shareholders and debtholders. With higher growth opportunities, firms are expected to engage in more project and investment opportunities. Firms will have to find means to finance the given opportunities. However, external financing is expensive with higher expected agency costs. Thus, higher cash levels are needed especially when the cost of external financing is costlier resulted from information asymmetry. Based on the discussion, it is expected that the relationship between cash-holding and growth opportunities is positive.

Hypothesis 1: There is a positive relationship between growth opportunities and corporate cash holdings.

\subsection{Firm Size}

Previous studies in cash holding highlighted the vital role of firm size. Transaction cost models demonstrate that the economies of scale exist in cash holdings (Baumol, 1952). Larger companies have better access to financial markets in general. However, smaller firms not only face higher constraints in borrowing but also prone to financial distress because of severe information asymmetries (Fazzari, Hubbard, Petersen, Blinder, \& Poterba, 1988; Kim et al., 1998). Therefore, the level of cash in smaller firms are expected to be higher due to costly external financing. However, larger firms are considered to be more diversified. The managers in large companies thus have better flexibility in financial policies and less bankruptcy risk (AlNajjar, 2011). In turn, the cash levels are higher in such firms.

According to Ozkan and Ozkan (2004), the size of a firm may serve as a proxy for information asymmetry. Lesser information asymmetries provide easier access to financing. It also allows greater diversification of activities for bigger companies. Hence, cash holdings are expected to be small for bigger firms. Several studies confirmed a negative effect of firm size on cash holdings, measuring firm size both using assets (Gao, Harford, \& Li, 2013; Opler et al., 1999). Accordingly, the link between cash holdings and firm size are expected to be negative. Company size (SIZE) is measured by the natural logarithm of total assets.

Hypothesis 2: There is a negative association between firm size and cash holdings.

\subsection{Cash Flow}

Kim et al. (1998) postulate that cash flows serve as a replacement for cash. Based on this perspective, firms with higher cash flows tend to maintain lesser cash. The need to hold cash reduced if a firm has sufficient cash flow. Having cash flow provides a ready source of liquidity (Ferreira \& Vilela, 2004; Kim et al., 1998). A negative relationship is predicted based on the Trade-off theory. On the contrary, if it is in line with the pecking order theory, a positive relationship will be expected. Firms with higher cash flow are more likely to hold most of their assets in the form of cash (Ferreira \& Vilela, 2004). Firms use liquid reserves to fund new investments. Therefore, higher cash flows will lead to higher liquid reserves as the firms need that as the primary source of financing (Deloof, 2003; Martínez-Sola, García-Teruel, \& Martínez-Solano, 2013). This is called the financing motive for holding cash. Besides, the tendency to maintain a high level of cash can also be driven by precautionary motive (Deloof, 2003).

The earnings before interest and taxes (EBIT) is added with depreciation and amortisation minus with interest expenses, tax and ordinary dividends to measure operating cash flow, It is then divided by the total assets (Hill, Fuller, Kelly, \& Washam, 2013). As the prediction based on the Pecking Order and Trade-off Theory is contradicted to each other, the expected relationship between cash flow and cash levels remain inconclusive. The hypothesis on the expected impact of cash flow on cash holdings is therefore formulated as follow.

Hypothesis 3: There is a negative/positive association between cash flow and cash holdings.

\subsection{Cash Flow Volatility}

The Trade-off theory states that firms have higher cash flow volatility and therefore would accumulate more cash as a precautionary measure (Miller \& Orr, 1966). As cash flow volatility increase, companies are prone to accumulating higher level of cash to meet its financial obligations (Opler et al., 1999). Hence, we expect that cash flow uncertainty is positively related to corporate cash holdings. There is a need to reserve a higher level of cash as the firms are exposed to a higher frequency of cash flow shortages.

Han and Qiu (2007) found a positive relationship between cash flow volatility and the cash holdings. Firms tend to increase their cash holdings as there is an increase in cash flow volatility, mainly if the firm is financially constrained. Interestingly, no such relationship was found for unconstrained firms. This difference is probably due to the precautionary motive for holding cash. Financially constrained firms are firms that cannot fund all positive 
NPV projects, because of borrowing constraints. Hence, they need to keep a buffer, since otherwise, they would have to forego promising investment opportunities. Unconstrained firms have better access to external financing and thus don't need precautionary cash holdings that much. This study, therefore, hypothesises a positive effect of cash flow volatility on the level of cash holdings.

Hypothesis 4: There is a positive association between cash flow volatility and cash holdings.

\subsection{Liquid Asset Substitutes}

Firms may have some other liquid assets as a replacement for cash. For example, net working capital serves as an alternative to cash regarding liquidity. When a firm already has a lot of liquid assets other than cash, the need for large cash holdings goes down. When substitutes for cash are already abundantly in place, the call for cash holdings is weakened. Liquidity is most often measured as net working capital. The net working capital is measured by current assets minus current liabilities divided by total assets. It thus measures the size of liquid assets, excluding cash. Several studies have confirmed the negative effect of liquidity on cash holdings (D'Mello, Krishnaswami, \& Larkin, 2008; Ozkan \& Ozkan, 2004).

Trade-off theory predicts a negative relationship between liquid asset substitutes and cash holdings (Al-Najjar, 2011; Ozkan \& Ozkan, 2004). This is due to the convertibility of liquid assets other than cash into cash. Thus, a negative relationship between asset liquidity and cash holdings is expected. The following hypothesis is formulated:

Hypothesis 5: There is a negative relationship between asset liquidity and cash holdings.

\subsection{Leverage}

Just like the presence of liquid assets other than cash, leverage may substitute for cash holdings too. It is an alternative way of funding. If leverage is already high, additional cash holdings may be redundant. A negative association between leverage and cash holdings would is expected. Another issue is the persistence of leverage policy. Leverage reflects the past financing behaviour of the firm, which is likely to persist in the future. Firms that are currently highly levered have experience in taking on loans and may also have a good credit rating. Therefore, these firms have a good bargaining position when negotiating new debt contracts. Hence, firms having large amounts of debt are more likely to issue debt in the future, so that large cash holdings are unnecessary.

One could also argue that higher leverage increases the possibility of financial distress. Firms with high leverage may want to make up for this by taking on additional precautionary cash. High leveraged firms are subject to the discipline and monitoring of the financial markets. Thus, less leveraged firms tend to accumulate more cash. Following this reasoning, leverage and cash holdings should be positively related. However, leverage is measured using the ratio of debt to sales. Based on the previous empirical findings and the trade-off theory, the following hypothesis is thus formulated.

Hypothesis 6: There is a negative relationship between leverage and cash holdings.

\subsection{Capital Expenditure}

Capital expenditures (CAPEX) represent cash outflows for the firm. Firms with large capital expenditures are firms making large investments. All other investments are just costs to the firm, so it is not reasonable that firms stockpile cash to fund capital expenditures. Therefore, firms are not expected to hold a buffer of liquid assets when facing large capital expenditures. Based on the pecking order theory, their cash holdings will be smaller, because CAPEX is being paid using internal funds. Firms with large capital expenditures will first draw down their cash holdings before addressing external financing. These firms spend money, rather than stockpile it. Thus, a negative relationship between the two is expected.

Past literature finds that capital expenditures increase a firm's borrowing capacity. By employing assets as collateral, the firm's needs for cash reserves can be lessened. Moreover, as productivity shocks that caused an increase in investments may result in a lower level of cash (Riddick \& Whited 2009). Therefore, capital expenditure is expected to be negatively related to cash holdings.

Hypothesis 7: There is a negative relationship between capital expenditure and cash holdings.

\subsection{Dividend}

Paying dividends reduces cash holdings directly because payouts are a cash outflow to the firm. The higher the dividends are, the less cash is available to stockpile. On the other hand, a dividend-paying firm can easily raise additional funds by cutting the dividend. Therefore, dividend payout is negatively correlated with cash holdings (Gao et al., 2013; Opler et al., 1999; Subramaniam, Tang, Yue, \& Zhou, 2011). By reducing dividends payout or disposing of non-financial assets, financially constrained firms can increase cash balances. Also, dividends may also serve as a proxy for financial soundness. For instance, 
Almeida, Campello, and Weisbach (2004) consider firms with no dividend payout as financially constrained. Besides, firms which pay dividend enjoy external financing at a lower cost due to better track record. Therefore, dividend payment status needs to be treated with due diligence as it would signal the public on the firm's condition. Besides, a negative effect of dividend on liquid corporate assets is expected.

Hypothesis 8: There is a negative relationship between dividends and cash holdings.

\section{Methodology}

\subsection{Sample and Data}

The sample in this study comprises of listed hospitality firms on the Bursa Malaysia during 2002 to 2013. Although the analysis is from the year 2002 to 2013, the dataset used in this study is from the year 1999 to 2013 due to the requirements of the model, i.e., lag and lead values. All data were gathered from Datastream International Database and the ISI Emerging Markets Database from EMIS. The sample for testing the hypotheses is selected based on the criteria where all firms are listed on Bursa Malaysia. The reason only listed firms were chosen is primarily due to the reliability and availability of the financial statements.

The sample was drawn from 22 hospitality firms listed on the Bursa Malaysia. The hospitality firms are identified using the North American Industrial Classification System (NAICS) code available in EMIS database: Arts, Entertainment and Recreation (71), Accommodation (721), Accommodation and Food Services (72), Food Services and Drinking Places (722). Only non-financial firms are included in the study. Firm-years with insufficient data are omitted from the sample. For instance, companies which do not have data starting from the year 1999 are excluded from the data required for computation of variability of cash flow which equals to the standard deviation of cash flows for at least past three years are missing. After taking out firms with lack of data in estimating the dependent and independent variables and adjusted for outliers, the final sample consists of 19 companies.

A comparative study was conducted to test if there are any significant differences between hospitality and nonhospitality firms. Thus, a sample of non-hospitality firms was drawn. All firms listed on the Main Board of the Bursa Malaysia which have complete data from 1999 to 2013 are included. Like previous studies, the finance and regulated sectors are exempted from the study because these firms are highly regulated and must maintain a certain level of cash as part of their regulatory compliance. Therefore, the result of this research would be affected. Industries such as the technology and mining which have less than ten firms are excluded. It is due to incomplete data. The final sample consists of 1176 observation. Of these, 948 observations belong to the non-hospitality industry and 228 hospitality firms.

\subsection{Variable Measurement}

The summary of variable measurement is presented in Table 2. The primary dependent variable is CASH which is measured using the cash ratio. The independent variables are mainly the firm characteristics. There is a total of eight variables which include: Growth opportunities, firm size, cash flow, cash flow variability, leverage, liquidity asset substitutes, capital expenditures and dividend.

Table 2: Summary of Variables Measurement

\begin{tabular}{|c|c|c|}
\hline Variable & & Description \\
\hline Cash ratio & $\mathrm{CASH}$ & Cash \& Cash equivalent)/ Total Assets \\
\hline $\begin{array}{c}\text { Growth } \\
\text { opportunities }\end{array}$ & GRO & Market to book ratio \\
\hline Firm size & SIZE & Natural logarithm of total assets \\
\hline Cash flow & $\mathrm{CF}$ & $\begin{array}{l}\text { (Earnings before tax }+ \text { depreciation } \& \\
\text { amortization) / Total assets }\end{array}$ \\
\hline $\begin{array}{l}\text { Cash Flow } \\
\text { Variability }\end{array}$ & VAR & $\begin{array}{l}\text { the standard deviation of the first } \\
\text { difference of OCF for the previous three } \\
\text { years }\end{array}$ \\
\hline Leverage & LEV & Total liabilities/ Total assets \\
\hline $\begin{array}{l}\text { Liquidity } \\
\text { asset } \\
\text { substitutes }\end{array}$ & LIQ & $\begin{array}{l}\text { (Current assets- current liabilities- cash \& } \\
\text { equivalents)/ Total assets. }\end{array}$ \\
\hline $\begin{array}{c}\text { Capital } \\
\text { expenditures }\end{array}$ & $\begin{array}{l}\text { CAPE } \\
X\end{array}$ & Total capital expenditures \\
\hline Dividend & DIV & $\begin{array}{l}\text { Dummy variable: } 1-\text { if dividend is paid; } \\
0=\text { if dividend is not paid }\end{array}$ \\
\hline
\end{tabular}

\subsection{Research Models}

Similar to Bigelli and Sánchez-Vidal (2012), we assume cash holdings is not adjusted immediately following the changes in the explanatory variables of cash holdings. Following Ozkan and Ozkan (2004), each of the $i_{\text {th }}$ company has an optimal cash level at year $t$, the function of the explanatory variables $x_{\mathrm{k}}$, and an error term $\mu$, i.e.:

$$
\begin{aligned}
& \operatorname{Cash}_{i t}^{*}=\alpha+\sum_{k} \beta_{k} x_{k i t}+\mu_{i t} \\
& \operatorname{Cash}_{i t}-\operatorname{Cash}_{i t-1}=\lambda\left(\operatorname{Cash}_{i t}^{*}-\operatorname{Cash}_{i t-1}\right)
\end{aligned}
$$

where $\alpha$ is the intercept. The $\lambda$ indicates the proportion 
of the adjustment to the optimal level which range from 0 to 1 . When $\lambda$ equals to 1 , the firm adjusts immediately. On the other hand, a value of 0 indicates that it is not efficient for firms to adjust its cash level due to high adjustment costs. To study the relationship between the identified variables and cash holdings, the determinants identified in the model by Opler et al. (1999) is adopted.

$$
\begin{aligned}
& \text { CASH }_{i t}=\delta_{0}+\delta_{1} C_{C A S H_{i t-1}}+\delta_{2} G O_{i t}+\delta_{3} \text { SIZE }_{i t}+ \\
& \delta_{4} C F_{i t}+\delta_{5} V A R_{i t}+\delta_{6} L E V_{i t}+\delta_{7} L I Q_{i t}+\delta_{8} C A P E X_{i t}+ \\
& \delta_{9} D I V_{i t}+\eta_{i}+\varphi_{t}+\varepsilon_{i t}
\end{aligned}
$$

where: $\delta_{0}=\alpha \lambda ; \delta_{1}=1-\lambda ; \delta_{k}=\lambda \beta_{k} ; \varepsilon_{i t}=\lambda \mu_{i t}$

The equation (3) is obtained by substituting Equation (1) into Equation (2). $\varphi_{t}$ represents the year dummy variables which reflect the impact of external economic environment that all firms are exposed to in a given year. $\eta_{i}$ indicates the unobservable time-invariant attributes of each company which could impact the cash holdings level. Both $\varphi_{t}$ and $\eta_{i}$ could impact their level of cash holdings and were added in equation (3). Since the lagged dependent variable are included in this adjustment model, both $\mathrm{CASH}_{\mathrm{i}, \mathrm{t}}$ and $\mathrm{CASH}_{\mathrm{i}, \mathrm{t}-1}$ are likely to be correlated with the $\eta_{i}$ term that does not va ary through time implying that an ordinary least squares estimator is biased and inconsistent. Furthermore, another source of bias may arise from possible endogeneity problems due to shocks that jointly impact the cash ratio and the exogenous variables and omitted variables bias. To address this problem, we follow Bigelli and Sánchez-Vidal (2012) and Guizani, (2017) to estimate the model by using instrumental variable estimators. We adopted the General Method of Moments (GMM) developed by Arellano and Bond (1991).

Unlike other static panel model, GMM offers better parameter estimates. It uses the instruments that are acquired from the orthogonality conditions that present between the lagged values of the variables and disturbances terms (Arellano \& Bond, 1991). The methodology assumes that there is no second-order serial correlation when lagged variables is used as instruments. Thus, the Arellano and Bond is included to test for the absence of second-order serial correlation. Furthermore, as introduced in the context of GMM by Hansen (1982), we test for the absence of correlation between the instruments and the error term using Sargan-Hansen overidentifying restrictions test.

\section{Results and Discussion}

\subsection{Descriptive Analysis}

For all 1067 observation in the sample, Table 3 shows the changes in the mean proportion of cash ratio by the hospitality and non-hospitality firms along the sample years. Consistent with prior literature, hospitality firms held less cash compared to non-hospitality firms. The figures show that there is an increasing trend of cash observed among Malaysian firms in the 2002 to 2013 period. It is similar to the findings by Bates and Kahle (2009) for US public firms. The mean cash holdings represent about 9.95\% (11.7\%) of total assets in 2013 compared to $5.41 \%$ (10.4\%) in the year

\begin{tabular}{|c|c|c|c|c|c|c|c|c|c|c|c|c|}
\hline & 2002 & 2003 & 2004 & 2005 & 2006 & 2007 & 2008 & 2009 & 2010 & 2011 & 2012 & 2013 \\
\hline Hospitality & 0.0541 & 0.0628 & 0.0919 & 0.0701 & 0.0684 & 0.106 & 0.114 & 0.103 & 0.101 & 0.0951 & 0.109 & 0.0995 \\
\hline Non Hospitality & 0.104 & 0.0885 & 0.0968 & 0.118 & 0.106 & 0.124 & 0.118 & 0.125 & 0.139 & 0.13 & 0.128 & 0.117 \\
\hline
\end{tabular}
2002 in hospitality firms (non-hospitality firms).

Table 3: Comparison of Cash Ratio (the Year 2002 to 2013)

Table 4 shows the summary statistic for the major variables tested in the analysis. The mean cash ratio for Malaysia public listed firms is recorded at an average $11.2 \%$ of total assets. Consistent with past studies, the figures range between 8 to $12 \%$ level which was found among public companies in the US (D'Mello et al., 2008; Fritz Foley, Hartzell, Titman, \& Twite, 2007; Kim et al., 1998). The median of cash holdings for Malaysian companies equals $8.23 \%$ of total assets. The median values found is lower compared to those who were documented by Ferreira and Vilela (2004) and Ozkan and Ozkan (2004). Previous studies recorded $9.1 \%$ and $5.9 \%$ for EMU and UK listed firms respectively.

Median values are below the average in hospitality firms as presented in Table 4. Similar to Kusnadi (2011), fewer cash holdings are observed among hospitality firms (where the mean and median values are $9.05 \%$ and $6.77 \%$ respectively), and non-hospitality firms (where the mean and median values are $11.9 \%$ and $8.64 \%$ respectively). The two- sample t-test and Wilcoxon-test both reject the null that cash holdings in non-hospitality firms are the same as that in hospitality firms at the $1 \%$ level. Overall, the results support the hypothesis that non-hospitality firms tend to hold more cash than hospitality firms. On average, cash holdings in non-hospitality firms are approximately $32 \%$ more than hospitality firms. This variation between the firms shows that industry is likely an essential determinant of cash holdings. 
Table 4: Description of exogeneous variables

\begin{tabular}{|c|c|c|c|c|c|c|}
\hline & Variable & Mean & p25 & Median & p75 & SD \\
\hline \multirow[t]{9}{*}{ Non-hospitality } & cash & $0.118^{* * *}$ & 0.0458 & $0.0864 * * *$ & 0.150 & 0.112 \\
\hline & gro & $0.818^{* * *}$ & 0.360 & $0.610 * * *$ & 1.030 & 0.773 \\
\hline & size & $5.752 * * *$ & 4.506 & $5.448 * * *$ & 6.939 & 1.649 \\
\hline & $\mathrm{cf}$ & $0.0519 * * *$ & 0.0085 & $0.0475^{* * *}$ & 0.0916 & 0.0977 \\
\hline & var & 0.129 & 0.0110 & 0.0240 & 0.0413 & 1.441 \\
\hline & lev & 0.451 & 0.290 & 0.447 & 0.587 & 0.224 \\
\hline & liq & $0.0559 * * *$ & -0.0553 & $0.0328^{* * *}$ & 0.177 & 0.216 \\
\hline & capex & $0.0541^{* * *}$ & 0.00951 & $0.0278^{* * *}$ & 0.0745 & 0.0847 \\
\hline & $\operatorname{div}$ & $0.801^{*}$ & 1 & 1 & 1 & 0.400 \\
\hline \multirow[t]{9}{*}{ Hospitality } & cash & $0.0905 * * *$ & 0.0292 & $0.0677^{* * *}$ & 0.128 & 0.0813 \\
\hline & gro & $0.550 * * *$ & 0.240 & $0.400 * * *$ & 0.680 & 0.467 \\
\hline & size & $6.219 * * *$ & 4.996 & $6.302 * * *$ & 7.204 & 1.525 \\
\hline & $\mathrm{cf}$ & $0.0158 * * *$ & -0.00833 & $0.0194 * * *$ & 0.0411 & 0.0700 \\
\hline & var & 0.0344 & 0.0112 & 0.0238 & 0.0427 & 0.0387 \\
\hline & lev & 0.430 & 0.285 & 0.434 & 0.558 & 0.190 \\
\hline & liq & $-0.0179 * * *$ & -0.0776 & $-0.0110 * * *$ & 0.0569 & 0.117 \\
\hline & capex & $0.0362 * * *$ & 0.00618 & $0.0149 * * *$ & 0.0379 & 0.0733 \\
\hline & div & $0.745^{*}$ & 0 & 1 & 1 & 0.437 \\
\hline \multirow[t]{9}{*}{ Total } & cash & $0.112 * * *$ & 0.0419 & $0.0823 * * *$ & 0.145 & 0.107 \\
\hline & gro & $0.764 * * *$ & 0.320 & $0.570 * * *$ & 0.970 & 0.730 \\
\hline & size & $5.847 * * *$ & 4.554 & $5.643 * * *$ & 7.041 & 1.635 \\
\hline & $\mathrm{cf}$ & $0.0446^{* * *}$ & 0.00497 & 0.0379 *** & 0.0876 & 0.0939 \\
\hline & var & 0.110 & 0.0110 & 0.0240 & 0.0415 & 1.284 \\
\hline & lev & 0.447 & 0.289 & 0.444 & 0.581 & 0.217 \\
\hline & $\operatorname{liq}$ & $0.0410 * * *$ & -0.0588 & $0.0191 * * *$ & 0.145 & 0.202 \\
\hline & capex & $0.0505 * * *$ & 0.00821 & $0.0244 * * *$ & 0.0665 & 0.0828 \\
\hline & div & $0.790^{*}$ & 1 & 1 & 1 & 0.408 \\
\hline
\end{tabular}

Test statistics of the t-test and the Wilcoxon-test of differences in cash holdings and firm characteristics between non-hospitality firms and hos pitality firms are given in superscript. $* * *, * *$ and $*$ denoting statistical significance at the $1 \%, 5 \%$ and $10 \%$ levels, respectively.

\subsection{Correlation Analysis}

Table 5 reports the correlation matrix and variance inflation factors (VIF) for the explanatory variables used in this study. The obtained results from the variation inflation factor (VIF) test are less than 2 in general. This does not suggest the presence of any severe multicollinearity in our regression models.

Table 5: Correlation Matrix

\begin{tabular}{|c|c|c|c|c|c|c|c|c|c|c|}
\hline \multicolumn{11}{|c|}{ HOSPITALITY FIRMS } \\
\hline & cash & gro & size & $\mathrm{cf}$ & var & lev & liq & capex & div & VIF \\
\hline cash & 1 & & & & & & & & & \\
\hline gro & $0.261 * * *$ & 1 & & & & & & & & 1.29 \\
\hline size & $-0.437 * * *$ & $0.161 * *$ & 1 & & & & & & & 1.38 \\
\hline $\mathrm{cf}$ & $0.190 * * *$ & $0.419 * * *$ & $0.270 * * *$ & 1 & & & & & & 1.54 \\
\hline var & 0.0651 & 0.00134 & $-0.210 * * *$ & -0.0603 & 1 & & & & & 1.16 \\
\hline lev & -0.0511 & $-0.283 * * *$ & $0.241 * * *$ & $-0.283^{* * *}$ & 0.0192 & 1 & & & & 1.34 \\
\hline liq & $-0.310^{* * *}$ & $0.157^{* *}$ & 0.0402 & $0.204 * * *$ & -0.102 & $-0.202 * * *$ & 1 & & & 1.09 \\
\hline capex & $-0.146^{* *}$ & -0.0280 & $-0.174 * *$ & -0.0505 & 0.0732 & -0.0478 & 0.0215 & 1 & & 1.03 \\
\hline div & $0.250 * * *$ & $0.174 * *$ & $0.313^{* * *}$ & $0.363 * * *$ & $-0.315^{* * *}$ & -0.0910 & 0.0260 & $-0.134 * *$ & 1 & 1.34 \\
\hline
\end{tabular}




\begin{tabular}{|c|c|c|c|c|c|c|c|c|c|c|}
\hline \multicolumn{11}{|c|}{ NON-HOSPITALITY FIRMS } \\
\hline & cash & gro & size & $\mathrm{cf}$ & var & lev & liq & capex & $\operatorname{div}$ & VIF \\
\hline cash & 1 & & & & & & & & & \\
\hline gro & $0.162^{* * *}$ & 1 & & & & & & & & 1.17 \\
\hline size & -0.0427 & $0.117^{* * *}$ & 1 & & & & & & & 1.27 \\
\hline $\mathrm{cf}$ & $0.245^{* * *}$ & $0.227 * * *$ & $-0.120 * * *$ & 1 & & & & & & 1.39 \\
\hline var & 0.0537 & \begin{tabular}{|c|}
-0.000991 \\
\end{tabular} & $-0.0748^{* *}$ & 0.0552 & 1 & & & & & 1.03 \\
\hline lev & $-0.237^{* * * *}$ & $-0.178 * * *$ & $0.310^{* * *}$ & $-0.367^{* * * *}$ & -0.0302 & 1 & & & & 1.6 \\
\hline liq & $-0.0689^{* *}$ & 0.0282 & $-0.286 * * *$ & $0.264 * * *$ & $0.0989^{* * *}$ & $-0.516^{* * *}$ & 1 & & & 1.51 \\
\hline capex & $0.100^{* * *}$ & $0.154 * * *$ & -0.0178 & $0.0659^{*}$ & -0.0212 & 0.00942 & $-0.157^{* * * *}$ & 1 & & 1.08 \\
\hline div & 0.00644 & 0.0533 & $0.242 * * *$ & $0.165^{* * *}$ & $-0.103 * * *$ & -0.0512 & -0.000606 & $-0.0871 * *$ & 1 & 1.13 \\
\hline
\end{tabular}

\subsection{Determinants of Cash Holdings}

Majority of the corporate decisions are endogenously determined; therefore, the endogeneity problem has been widely discussed in past studies. Similar to Chen (2008) and Ozkan and Ozkan (2004), we thus perform both static panel and dynamic panel estimations to alleviate the potential endogeneity problem.

We test the formulated hypotheses in section 0 by using the pooled regression analysis. Table 6 presents the results and the theoretical support. In addition, diagnostic testing was performed, and there was no multicollinearity. The results are shown in 3 columns. Column 1 presents the static model in Equation 1 using the OLS technique with standard errors. The second column summarises the results from the fixed effects model. The inclusion of the fixed effects should alleviate the influence of the related variables if the coefficients of the relationship measurements happen due to an omitted firm-specific factor. The last column reestimated the model using the Fama-MacBeth model. We use this model to estimate a cross-sectional regression for each year. According to Itzkowitz (2013), this approach is more effective because it treats each year as an independent cross-section. Besides, it also helps overcome the serial correlation problem in the error term of cross-sectional regressions.

While the fixed effects regressions control for firm heterogeneity and time factors, the regressions may be affected by potential endogeneity. Also, there is ample evidence that firms have implicit target levels of cash holdings (Opler et al., 1999; Ozkan \& Ozkan, 2004), which can be modelled by taking one-period lag of the dependent variable among the independent variables. However, estimating such a model using fixed-effects regression leads to inefficient and inconsistent standard errors as there is a link between the lagged dependent variable and standard errors (Nickell, 1981). Therefore, we estimated the model in Equation 3 with a system GMM model of (Blundell \& Bond, 1998) as shown in Table 6 and illustrated in the following section. Two-step system GMM were performed, and the results are presented as follow.

Table 7 shows the results of the determinants of cash holdings based on GMM regressions. Two-stage GMM estimator is used for all estimations. According to Blundell and Bond (1998), two-stage GMM is preferred over onestage as it is more efficient. Residuals from one-stage estimation are used to construct an asymptotically weighted optimum matrix in two-stage GMM. Hansen test is carried out, and the instrument is valid. Second-order serial correlation is not present in all the three models thus confirming consistent estimations. The lagged dependent variable is significant on all models. This implies that the dynamic GMM is a suitable estimator. Therefore, the empirical results are useful for statistical inference.

The coefficient on the hospitality firm indicator variable (HOSP) is -0.46 for the full sample (column 1). This result indicates that hospitality firms hold approximately $37 \%\left(\mathrm{e}^{-}\right.$ ${ }^{0.46}-1$ ) less cash than non-hospitality firms. Based on our model, the trade-off theory supports most of the observed relationship. Firm size is found to have a negative relationship with cash holdings. Firms hold significantly higher amounts of cash as the volatility of cash flows increase. These results are consistent with the one documented by Opler et al. (1999).

As highlighted by Gao et al. (2013), corporate cash policy should "balance the precautionary demand (Keynes, 1936; Baumol, 1952; Miller \& Orr, 1966) against agency problems (Jensen, 1986; Stulz, 1990)". Given the higher costs of accessing external capital; exposure to high seasonality and uncertainties, the precautionary motive should be stronger for hospitality firms. Nevertheless, based on the findings by Harford, Mansi, and Maxwell (2008), the worse-governed firms in a sample of public listed U.S. firms hold less cash as they utilize rather than maintain cash reserves. Therefore, it could be due to financing frictions if we find that non-hospitality firms hold lower cash reserves than hospitality firms. 
Table 6: Determinants of Cash Holdings (Static Panel Regression)

\begin{tabular}{|c|c|c|c|c|c|c|c|c|c|}
\hline & \multicolumn{3}{|c|}{ FULL SAMPLE } & \multicolumn{3}{|c|}{ HOSPITALITY FIRMS } & \multicolumn{3}{|c|}{ NON-HOSPITALITY FIRMS } \\
\hline VARIABLES & Pooled OLS & $\begin{array}{c}\text { FE with } \\
\text { Hetero \& } \\
\text { Serial } \\
\text { Correlation }\end{array}$ & $\begin{array}{l}\text { Fama- } \\
\text { Macbeth }\end{array}$ & $\begin{array}{l}\text { Pooled } \\
\text { OLS }\end{array}$ & $\begin{array}{c}\text { RE with } \\
\text { Hetero \& } \\
\text { Serial } \\
\text { Correlation }\end{array}$ & $\begin{array}{l}\text { Fama- } \\
\text { Macbeth }\end{array}$ & $\begin{array}{l}\text { Pooled } \\
\text { OLS }\end{array}$ & $\begin{array}{c}\text { FE with } \\
\text { Hetero \& } \\
\text { Serial } \\
\text { Correlation }\end{array}$ & $\begin{array}{l}\text { Fama- } \\
\text { Macbeth }\end{array}$ \\
\hline \multicolumn{10}{|l|}{ lncash } \\
\hline \multirow[t]{2}{*}{ HOSP } & $-0.215^{* * *}$ & & $-0.174 * *$ & & & & & & \\
\hline & $(-2.889)$ & & $(0.0677)$ & & & & & & \\
\hline \multirow[t]{2}{*}{ gro } & $0.106^{* *}$ & 0.106 & $0.168 * *$ & $0.434 * * *$ & $0.506^{* *}$ & $0.717 * *$ & $0.0721 *$ & 0.0617 & $0.206^{* *}$ \\
\hline & $(2.467)$ & $(1.533)$ & $(0.0718)$ & $(2.869)$ & $(2.383)$ & $(0.279)$ & $(1.698)$ & $(0.961)$ & $(0.0831)$ \\
\hline \multirow[t]{2}{*}{ Size } & $-0.0588 * * *$ & -0.133 & $0.0697 * * *$ & $-0.251 * * *$ & $-0.342 * * *$ & $0.206^{* * *}$ & -0.00874 & -0.103 & -0.0195 \\
\hline & $(2.938)$ & $(1.566)$ & $(0.0191)$ & $(5.244)$ & $(3.536)$ & $(0.0475)$ & $(0.412)$ & $(1.174)$ & $(0.0204)$ \\
\hline \multirow[t]{2}{*}{$\mathrm{CF}$} & $3.016^{* * *}$ & $2.397 * * *$ & $2.734 * * *$ & -1.329 & -0.750 & -3.688 & $3.316^{* * *}$ & $2.903 * * *$ & $3.097 * * *$ \\
\hline & $(7.070)$ & (3.723) & $(0.367)$ & $(-1.216)$ & $(-0.646)$ & $(2.724)$ & $(7.455)$ & $(4.934)$ & $(0.493)$ \\
\hline \multirow[t]{2}{*}{ var } & 0.0280 & $0.0318 * * *$ & 1.805 & 2.528 & 0.586 & 6.516 & 0.0261 & $0.0311 * * *$ & 2.278 \\
\hline & $(1.253)$ & (3.596) & $(1.284)$ & $(1.462)$ & $(0.355)$ & $(4.951)$ & $(1.227)$ & $(3.411)$ & $(1.486)$ \\
\hline \multirow[t]{2}{*}{ lev } & $-0.422 * * *$ & $-1.423^{* * *}$ & $-0.453 * *$ & -0.421 & -0.910 & $0.932 *$ & $-0.720 * * *$ & $-1.675^{* * *}$ & $-0.643 * * *$ \\
\hline & $(-2.606)$ & $(-2.991)$ & $(0.147)$ & $(1.109)$ & $(-1.368)$ & $(0.477)$ & $(-4.221)$ & $(-3.055)$ & $(0.159)$ \\
\hline \multirow[t]{2}{*}{ LIQ } & -0.0209 & -0.745 & 0.141 & $-2.781 * * *$ & $1.473 *$ & $2.139 * * *$ & $-0.499 * * *$ & $-1.135^{* *}$ & $-0.357 * *$ \\
\hline & $(-0.123)$ & $(-1.605)$ & $(0.101)$ & $(5.071)$ & $(1.765)$ & $(0.591)$ & $(-2.870)$ & $(-2.341)$ & $(0.117)$ \\
\hline \multirow[t]{2}{*}{ CAPEX } & 0.544 & -0.472 & $1.255^{* * *}$ & -1.351 & -0.783 & -3.945 & 0.794* & -0.450 & $1.080 * *$ \\
\hline & $(1.275)$ & $(-1.354)$ & $(0.326)$ & $(-1.270)$ & $(-1.313)$ & $(2.302)$ & $(1.789)$ & $(-1.030)$ & $(0.359)$ \\
\hline \multirow[t]{2}{*}{ Div } & -0.0391 & -0.0391 & 0.0474 & $0.409^{* *}$ & 0.0580 & $0.705 * * *$ & $-0.144 *$ & -0.0640 & -0.0772 \\
\hline & $(-0.505)$ & $(-0.416)$ & $(0.0981)$ & $(2.465)$ & $(0.355)$ & $(0.151)$ & $(-1.710)$ & $(-0.622)$ & $(0.103)$ \\
\hline \multirow[t]{2}{*}{ Constant } & $-2.931 * * *$ & $-2.862 * * *$ & $-3.231 * * *$ & $-5.129 * * *$ & $-4.902 * * *$ & $\begin{array}{c}- \\
5.497 * * *\end{array}$ & $-2.392 * * *$ & $-2.448 * * *$ & $-2.756 * * *$ \\
\hline & $(-21.13)$ & $(-4.824)$ & $(0.117)$ & $(-15.84)$ & $(-6.302)$ & $(0.304)$ & $(-16.03)$ & $(-3.937)$ & $(0.167)$ \\
\hline \multirow[t]{2}{*}{$\begin{array}{c}\text { Breusch-Pagan } \\
\text { LM Test }\end{array}$} & $1220.71 * * *$ & & & $182.68^{* * *}$ & & & $848.09 * * *$ & & \\
\hline & $(0.000)$ & & & $(0.000)$ & & & $(0.000)$ & & \\
\hline \multirow[t]{2}{*}{ Hausman Test } & & $20.8 * * *$ & & & & & & $19.96 * * *$ & \\
\hline & & $(0.0077)$ & & & & & & $(0.0105)$ & \\
\hline $\begin{array}{c}\text { Multicollinearity } \\
\text { (VIF) }\end{array}$ & 1.25 & & & 1.27 & & & 1.27 & & \\
\hline \multirow[t]{2}{*}{ Wald test } & & $32039.54 * * *$ & & & & & & $9175,70^{* * *}$ & \\
\hline & & $(0.000)$ & & & & & & $(0.000)$ & \\
\hline \multirow[t]{2}{*}{$\begin{array}{c}\text { Wooldridge test } \\
\text { (F-Stat) }\end{array}$} & & $54.622 * * *$ & & & & & & $52.637 * * *$ & \\
\hline & & $(0.000)$ & & & & & & $(0.000)$ & \\
\hline Observations & 1,031 & 1,031 & 1,031 & 213 & 213 & 213 & 818 & 818 & 818 \\
\hline R-squared & 0.128 & 0.133 & 0.207 & 0.326 & & 0.550 & 0.146 & 0.168 & 0.240 \\
\hline
\end{tabular}

t-statistics in parentheses

$* * * \mathrm{p}<0.01, * * \mathrm{p}<0.05, * \mathrm{p}<0.1$

Similar to Harford et al. (2008), the agency explanation of cash is only supported if the finding that non-hospitality firms have a higher level of cash holdings.

The significance of observed coefficients of two cashsubstitute variables supports the hypothesis. Results show that firms having more liquid asset substitute and net working capital hold lesser in cash which is consistent with the findings by Ozkan and Ozkan (2004) and Ferreira and Vilela (2004). We also include year dummies to study the possibility that some macroeconomic shocks can influence companies' cash balances. When year dummies are included in the regression model, some of the years are significant, while some variables have otherwise. These findings show that the impact of such variables on cash holdings could also affect by external events such as crisis.

We find a significant and negative impact of liquid asset substitutes (LIQ) on cash holding at the $1 \%$ level in the system GMM model. This is attributed to the fact that cash 
substitutes play an essential role in reducing the number of cash holdings. The result is congruous with past findings as discussed in section 0. However, contrary to the expectations, we found no significant association between the firm size (SIZE). This is in line with some previous studies (García-Teruel, Martínez-Solano, \& SánchezBallesta, 2009; Guney, Ozkan, \& Ozkan, 2007; Ozkan \& Ozkan, 2004). Thus, size might not be a determinant of cash holding for hospitality firms.

Table 7: Determinants of Cash Holdings (Two-step System GMM)

\begin{tabular}{|c|c|c|c|}
\hline VARIABLES & Full Sample & $\begin{array}{c}\text { Hospitality } \\
\text { Firms }\end{array}$ & $\begin{array}{c}\text { Non- } \\
\text { Hospitality } \\
\text { Firms }\end{array}$ \\
\hline \multicolumn{4}{|l|}{ lncash } \\
\hline \multirow[t]{2}{*}{ lncash $=\mathrm{L}$} & $0.389 * * *$ & $0.399 * * *$ & $0.438 * * *$ \\
\hline & $(22.60)$ & $(2.631)$ & $(34.81)$ \\
\hline \multirow[t]{2}{*}{ HOSP } & $-0.460 * * *$ & & \\
\hline & $(-2.723)$ & & \\
\hline \multirow[t]{2}{*}{ gro } & $0.126 * * *$ & 0.403 & $0.113 * * *$ \\
\hline & $(8.663)$ & $(1.387)$ & $(14.92)$ \\
\hline \multirow[t]{2}{*}{ Size } & $-0.179 * * *$ & -0.0464 & $-0.123 * * *$ \\
\hline & (7.099) & $(0.146)$ & $(8.523)$ \\
\hline \multirow[t]{2}{*}{$\mathrm{CF}$} & $1.460 * * *$ & 1.623 & $1.807 * * *$ \\
\hline & $(11.98)$ & $(0.475)$ & $(19.15)$ \\
\hline \multirow[t]{2}{*}{ var } & $0.0580 * * *$ & 2.822 & $0.0670 * * *$ \\
\hline & $(16.43)$ & $(0.743)$ & $(33.10)$ \\
\hline \multirow[t]{2}{*}{ lev } & $-1.037 * * *$ & -1.076 & $-0.665 * * *$ \\
\hline & $(-7.677)$ & $(-0.883)$ & $(-5.842)$ \\
\hline \multirow[t]{2}{*}{ LIQ } & -0.172 & $4.326 * * *$ & $-0.563 * * *$ \\
\hline & $(-1.011)$ & $(2.617)$ & $(-5.283)$ \\
\hline \multirow[t]{2}{*}{ CAPEX } & $-1.187 * * *$ & -2.303 & $-1.455 * * *$ \\
\hline & $(-6.321)$ & $(-0.488)$ & $(-9.440)$ \\
\hline \multirow[t]{2}{*}{ Div } & $-0.101 * * *$ & -0.141 & $-0.0762 * * *$ \\
\hline & $(-2.917)$ & $(-1.138)$ & $(-4.464)$ \\
\hline \multirow[t]{2}{*}{ Constant } & $-2.047 * * *$ & -1.579 & $-1.822 * * *$ \\
\hline & $(-11.35)$ & $(-0.733)$ & $(-15.87)$ \\
\hline \multirow[t]{2}{*}{ Sargan Test } & 69.60233 & 9.335003 & 69.64283 \\
\hline & $(0.2651)$ & $(1.000)$ & $(0.2934)$ \\
\hline Instruments valid? & Yes & Yes & Yes \\
\hline \multirow[t]{2}{*}{$\mathrm{AR}(1)$} & $-5.3743 * * *$ & $-2.175 * *$ & $-4.992 * * *$ \\
\hline & $(0.000)$ & $(0.0296)$ & $(0.000)$ \\
\hline \multirow[t]{2}{*}{$\mathrm{AR}(2)$} & -0.19009 & -0.71757 & -0.08261 \\
\hline & $(0.8492)$ & $(0.4730)$ & $(0.9342)$ \\
\hline Observations & 964 & 197 & 767 \\
\hline \multicolumn{4}{|l|}{ R-squared } \\
\hline \multicolumn{4}{|l|}{ Number of groups } \\
\hline Number of code & 98 & 19 & 79 \\
\hline
\end{tabular}

$\mathrm{t}$-statistics in parentheses

$* * * \mathrm{p}<0.01,{ }^{* *} \mathrm{p}<0.05,{ }^{*} \mathrm{p}<0.1$

\section{Conclusions}

There is only a handful of cash holdings research done in the context of Malaysia. Existing empirical literature on cash holdings predominantly focuses on public listed firms in the U.S. Some recent evidence also focuses either on large European listed firms. Although informative, generalisation across the entire industry and different contexts may be limited mainly to the emerging markets. Among the few existing studies which focus on emerging market is Wasiuzzaman (2014). A sample of 192 firms over from the year 2000 to 2007 is studied. The results show that firms in Malaysia do adjust to targeted cash level. However, the speed of adjustment is determined slower compared to that those in other countries. Financing constraints and market imperfections are essential determinants of cash holdings among public listed firms in Malaysia.

Malaysia is an ideal paradigm to study cash holdings decision among hospitality firms. Hospitality firms hold an average cash ratio which is less than $10 \%$ in Malaysia. Firm size and firm age are negatively related to the level of cash. Such firms are considered to be riskier and financially constrained. Therefore, there is a need to hold more cash compared to larger firms. These findings are aligned with the argument by the Trade-off Theory on the determinants of cash holdings. In addition, dividend payments are found to impact cash holdings as well. The cash level of firms which pay out dividends is prone to a higher level of cash. This could be due to lower agency costs of free cash flows. The paper aims to shed light on how firm characteristics affects corporate cash holdings in the context of hospitality firms in the emerging market. There is a need for relevant authorities and policymakers to study the issue of sustainability of the hospitality industry. Furthermore, reinforcing internal strength such as corporate liquidity by hospitality firm is vital for survival in a highly competitive environment in the long run.

\section{References}

Al-Najjar, B. (2011). The inter-relationship between capital structure and dividend policy: empirical evidence from Jordanian data. International Review of Applied Economics, 25(2), 209-224.

https://doi.org/10.1080/02692171.2010.483464

Almeida, H., Campello, M., \& Weisbach, M. S. (2004). The cash flow sensitivity of cash. Journal of Finance, 59(4), $1777-1804$. https://doi.org/10.1111/j.1540-6261.2004.00679.x

Arellano, M., \& Bond, S. (1991). Some Tests of Specification for Panel Data: Monte Carlo Evidence and an Application to Employment Equations. The Review 
of Economic Studies, 58(2), 277-297.

https://doi.org/10.2307/2297968

Bates, T. W., Kahle, K. M., \& Stulz, R. M. (2009). Why Do U. S. Firms Hold So Much than They Used To? Journal of Finance, 64(5), 1985-2021. https://doi.org/10.1111/j.1540-6261.2009.01492.x

Baumol, W. (1952). The transactions demand for cash: An inventory theoretic approach. The Quarterly Journal of Economics, 66(4), 545-556. Retrieved from http://www.jstor.org/stable/10.2307/1882104

Bharwani, S., \& Mathews, D. (2012). Risk identification and analysis in the hospitality industry: Practitioners' perspectives from India. Worldwide Hospitality and Tourism Themes, 4(5), 410-427. https://doi.org/10.1108/17554211211277851

Bigelli, M., \& Sánchez-Vidal, J. (2012). Cash holdings in private firms. Journal of Banking \& Finance, 36(1), 2635. https://doi.org/10.1016/j.jbankfin.2011.06.004

Blundell, R., \& Bond, S. (1998). Initial conditions and moment restrictions in dynamic panel data models. Journal of Econometrics, 87(1), 115-143. https://doi.org/10.1016/S0304-4076(98)00009-8

Booth, L., \& Zhou, J. (2013). Increase in Cash Holdings: Pervasive or Sector-Specific? Frontiers in Finance \& Economics, 10(2), 1-30. Retrieved from http://www.edwards.usask.ca/csfm/_files/presentations/j un zhou.pdf

Chen, Y.-R. (2008). Corporate Governance and Cash Holdings: Listed New Economy versus Old Economy Firms. Corporate Governance: An International Review, 16(5), 430-442. https://doi.org/10.1111/j.1467-8683.2008.00701.x

Choi, K., Roh, Y., \& Yoon, J. (2007). An Empirical Examination of Productivity of a Chain Restaurant Using Data Envelopment Analysis (DEA). International Journal of Quality and Productivity Management, 7(1), 47-67.

D’Mello, R., Krishnaswami, S., \& Larkin, P. J. (2008). Determinants of corporate cash holdings: Evidence from spin-offs. Journal of Banking and Finance, 32(7), 1209-1220. https://doi.org/10.1016/j.jbankfin.2007.10.005

Deloof, M. (2003). Does Working Capital Management Affect Corporate Profitability of Belgian Firms? Journal of Business Finance and Accounting, 30(3), 573-587.

Fazzari, S. M., Hubbard, R. G., \& Petersen, B. C. (1988). Financing Constraints and Corporate Investment. Brookings Papers on Economic Activity, 1, 141-195.

Ferreira, M. A., \& Vilela, A. S. (2004). Why Do Firms Hold Cash? Evidence from EMU Countries. European Financial Management, 10(2), 295-319.

https://doi.org/10.1111/j.1354-7798.2004.00251.x
Fritz Foley, C., Hartzell, J. C., Titman, S., \& Twite, G. (2007). Why do firms hold so much cash? A tax-based explanation. Journal of Financial Economics, 86(3), 579-607. https://doi.org/10.1016/j.jfineco.2006.11.006

Gao, H., Harford, J., \& Li, K. (2013). Determinants of corporate cash policy: Insights from private firms. Journal of Financial Economics, 109(3), 623-639. https://doi.org/10.1016/j.jfineco.2013.04.008

García-Teruel, P. J., Martínez-Solano, P., \& SánchezBallesta, J. P. (2009). Accruals quality and corporate cash holdings. Accounting and Finance, 49(1), 95-115. https://doi.org/10.1111/j.1467-629X.2008.00276.x

Guizani, M. (2017). The financial determinants of corporate cash holdings in an oil rich country: Evidence from Kingdom of Saudi Arabia. Borsa Istanbul Review, 17(3), 133-143. https://doi.org/10.1016/j.bir.2017.05.003

Guney, Y., Ozkan, A., \& Ozkan, N. (2007). International evidence on the non-linear impact of leverage on corporate cash holdings. Journal of Multinational Financial Management, 17(1), 45-60. https://doi.org/10.1016/j.mulfin.2006.03.003

Han, S., \& Qiu, J. (2007). Corporate precautionary cash holdings. Journal of Corporate Finance, 13(1), 43-57. https://doi.org/10.1016/j.jcorpfin.2006.05.002

Hansen, L. (1982). Large sample properties of generalized method of moments estimators. Econometrica: Journal of the Econometric Society, 50(4), 1029-1054. https://doi.org/10.2307/1912775

Hardin, W. G., Highfield, M. J., Hill, M. D., \& Kelly, G. W. (2009). The determinants of REIT cash holdings. Journal of Real Estate Finance and Economics, 39(1), 39-57. https://doi.org/10.1007/s11146-007-9103-1

Harford, J., Mansi, S. A., \& Maxwell, W. F. (2008). Corporate governance and firm cash holdings in the US. Journal of Financial Economics, 87(3), 535-555. https://doi.org/10.1016/j.jfineco.2007.04.002

Hill, M. D., Fuller, K. P., Kelly, G. W., \& Washam, J. O. (2013). Corporate cash holdings and political connections. Review of Quantitative Finance and Accounting, 42(1), 123-142. https://doi.org/10.1007/s11156-012-0336-6

Hsu, L., \& Jang, S. (2008). The Determinant of the Hospitality Industry's Unsystematic Risk: A Comparison Between Hotel and Restaurant Firms. International Journal of Hospitality \& Tourism Administration, 9(2), 105-127. https://doi.org/10.1080/15256480801907877

Hsu, W.-Y., Huang, Y. R., \& Lai, G. (2015). Corporate Governance and Cash Holdings: Evidence From the U.S. Property-Liability Insurance Industry. Journal of Risk and Insurance, 82(3), 715-748. https://doi.org/10.1111/jori.12049

Itzkowitz, J. (2013). Customers and cash: How 
relationships affect suppliers' cash holdings. Journal of Corporate Finance, 19, 159-180.

https://doi.org/10.1016/j.jcorpfin.2012.10.005

Jang, S., Park, K., \& Lee, J. E. (2011). Estimating Cashflow-at-Risk (CFaR): A Comparables Approach for Restaurant Firms. Cornell Hospitality Quarterly, 52(3), 232-240.

https://doi.org/10.1177/1938965510395746

Jang, S., Tang, C.-H., \& Chen, M.-H. (2008). Financing behaviors of hotel companies. International Journal of Hospitality Management, 27(3), 478-487. https://doi.org/10.1016/j.ijhm.2007.08.010

Jensen, M. C. (1986). Agency costs of free cash flow, corporate finance, and takeovers. The American Economic Review, 76(2), 323-329. https://doi.org/10.1017/cbo9780511609435.005

Keynes, J. M. (1936). General theory of employment, interest and money. London, UK: MacMillan.

Kim, C. S., Mauer, D. C., \& Sherman, A. E. (1998). The determinants of corporate liquidity: Theory and evidence. Journal of Financial and Quantitative Analysis, 33(3), 335-359. https://doi.org/10.2307/2331099

Kim, J., Kim, H., \& Woods, D. (2011). Determinants of corporate cash-holding levels: An empirical examination of the restaurant industry. International Journal of Hospitality Management, 30(3), 568-574. https://doi.org/10.1016/j.ijhm.2010.10.004

Kusnadi, Y. (2011). Do corporate governance mechanisms matter for cash holdings and firm value? Pacific-Basin Finance Journal, 19(5), 554-570.

https://doi.org/10.1016/j.pacfin.2011.04.002

Martínez-Sola, C., García-Teruel, P. J., \& Martínez-Solano, P. (2013). Corporate cash holding and firm value. Applied Economics, 45(2), 161-170. https://doi.org/10.1080/00036846.2011.595696

Miller, M., \& Orr, D. (1966). A Model of the Demand for Money by Firms. The Quarterly Journal of Economics, $80(3)$, 413-435. Retrieved from http://qje.oxfordjournals.org/content/80/3/413.short

Nickell, S. (1981). Biases in dynamic panel models with fixed effects. Econometrica, 49(6), 1417-1426. https://doi.org/10.2307/1911408

Oak, S., \& Iyengar, R. (2009). Investigating the differences in corporate governance between hospitality and nonhospitality firms. Advances in Hospitality and Leisure, 5(2009), 125-140. https://doi.org/10.1108/S1745-3542(2009)0000005011

Opler, T., Pinkowitz, L., Stulz, R., \& Williamson, R. (1999). The determinants and implications of corporate cash holdings. Journal of Financial Economics, 52(1), 3-46. https://doi.org/10.1016/S0304-405X(99)00003-3

Opler, T., Pinkowitz, L., Stulz, R., \& Williamson, R. (2001). Corporate cash holdings. Journal of Applied Corporate Finance, 14(1), 55-67.

https://doi.org/10.1111/j.1745-6622.2001.tb00320.x

Ozkan, A., \& Ozkan, N. (2004). Corporate cash holdings: An empirical investigation of UK companies. Journal of Banking \& Finance, 28(9), 2103-2134. https://doi.org/10.1016/j.jbankfin.2003.08.003

Park, K., \& Jang, S. (2014). Hospitality Finance and Managerial Accounting Research: Suggesting an Interdisciplinary Research Agenda. International Journal of Contemporary Hospitality Management, 26(5), 751-777. https://doi.org/10.1108/JJCHM-122013-0554

Pegg, S., Patterson, I., \& Gariddo, P. V. (2012). The impact of seasonality on tourism and hospitality operations in the alpine region of New South Wales, Australia. International Journal of Hospitality Management, 31(3), 659-666. https://doi.org/10.1016/j.ijhm.2011.09.001

Pizam, A., \& Shani, A. (2009). The Nature of the Hospitality Industry: Present and Future Managers' Perspectives. Anatolia, 20(1), 134-150. https://doi.org/10.1080/13032917.2009.10518900

Riddick, L. A., \& Whited, T. M. (2009). The Corporate Propensity to Save. Journal of Finance, 64(4), 17291766. https://doi.org/10.1111/j.1540-6261.2009.01478.x

Scott, D., \& McBoyle, G. (2007). Climate change adaptation in the ski industry. Mitigation and Adaptation Strategies for Global Change, 12(8), 14111431. https://doi.org/10.1007/s11027-006-9071-4

Stulz, R. (1990). Managerial discretion and optimal financing policies. Journal of Financial Economics, 26(1), 3-27.

https://doi.org/10.1016/0304-405X(90)90011-N

Subramaniam, V., Tang, T. T., Yue, H., \& Zhou, X. (2011). Firm structure and corporate cash holdings. Journal of Corporate Finance, 17(3), 759-773. https://doi.org/10.1016/j.jcorpfin.2010.06.002

Upneja, A., \& Dalbor, M. C. (2000). An examination of capital structure in the restaurant industry. The Journal of Hospitality Financial Management, 8(1), 70-71. https://doi.org/10.1080/10913211.2000.10653739

Wasiuzzaman, S. (2014). Analysis of corporate cash holdings of firms in Malaysia. Journal of Asia Business Studies, 8(2), 118-135.

https://doi.org/10.1108/JABS-10-2012-0048 